\title{
Correspondence
}

\section{The College and South Africa}

DEAR SIRS

Dr Sashidharan's letter (Bulletin, November 1983, 7, 208) continues his unflagging crusade to encourage the College to pursue a campaign against South Africa for its policy of apartheid.

The psychological effects of apartheid are doubtless deleterious and serious. For this, as well as other reasons, such a policy stands condemned by our Committee as it does by any thinking and feeling individual or organization. However, all adverse social conditions such as unemployment, poverty, social disruption, etc, often arising from political decisions, have such effects and yet our Committee does not consider these.

If Dr Sashidharan feels that the documents we considered in reaching our decisions are inadequate, it remains for him to supply more information, but this should refer to specific cases of psychiatric abuse as distinct from police brutality or allegations of the general effects on health produced by apartheid.

Our Committee remains available for information regarding political abuse of psychiatry in a world-wide context and is not pre-occupied with any particular country. It is, for example, currently investigating an allegation of participation in psychological torture methods by colleagues in Uruguay.

SidNey LeVINE

Special Committee on the

Oldham \& District General Hospital

Political Abuse of Psychiatry

Oldham

\section{Mental handicap services-the future}

\section{DeAr Sirs}

Over the past few years a number of policy statements concerning the needs of people with mental handicap have been published. $1.2,3.45$ None of them are referred to in the report approved by Council and published in the Bulletin (July 1983, 7, 131-34).

We are in the midst of exciting times for the development of services for mentally handicapped people. An enormous amount of interest has been generated both in this country and abroad. New partnerships have developed between members of different professions and between parents and professionals. Research into the development of new services has generated many ideas for the future and many Regional and District Health Authorities are now pushing ahead with forward looking plans to extend their services in collaboration with Local Authorities. Psychiatrists could play a key role in the implementation of these proposals, but if the document approved by Council represents the philosophy of the College, then psychiatrists will quite rapidly and quite rightly be left on the sidelines.

The document is a sad, disappointing and inadequate guide to the future. It reflects an insular and conservative view and will do little to enhance the reputation of the College as a forward-looking body.

The report fails to mention the most recent statement of government policy, the 1980 White Paper.' There is no reference to Care in the Community, ${ }^{2}$ the most likely source of funding for community-based services in the future; no reference to the rapidly growing body of research into service delivery; no reference to the expanding interest and work on normalization; ${ }^{3}$ no reference to the new services which are being based on the use of ordinary housing in the community; ${ }^{4}$ no reference to trends in service development in other parts of the world; no reference to the policy papers of the National Development Group; no mention of the Independent Development Council nor of its policy statements. ${ }^{3}$

Mentally handicapped people have a diversity of needs. Most of the evidence coming from the reports of the Development Team points to the need for more communitybased initiatives and wider range of choices for mentally handicapped people, particularly with regard to residential provision. By failing to indicate the way in which we, as psychiatrists, might be involved in expanding the range of initiatives and choices in the community, the document fails to indicate the direction for the future; it merely restates and repeats what has happened in the past.

Department of Mental Health

Ouver Russelu
REFERENCES

'Department of Health and Social Securtty (1980) Mental Handicap: Progress, Problems and Priorities. A Review of Mental Handicap Services in England since the 1971 White Paper. London: HMSO.

2Department of Health and Social Securtry (1981) Care in the Community. A Consultative Document on Moving Resources for Care in England. London: HMSO.

'O'BRIEN, J. \& TYNE, A. (1981) The Principle of Normalization: A Foundation for Effective Services. London: CMH.

‘King's Fund Centre (1980) An Ordinary Life: Comprehensive Locally Based Residential Services for Mentally Handicapped. London: King's Fund Centre.

'INDEPENDENT DeVELOPMENT COUNCIL FOR PEOPLe WITH MENTAL HANDicap (1982) Elements of a Comprehensive Local Service for People with Mental Handicap. London: IDC. 